\title{
ДОСВІД ОРГАНІЗАЦІЇ КОЛЕКТИВНОГО НАРОДНО- ІНСТРУМЕНТАЛЬНОГО ВИКОНАВСТВА В ПІДГОТОВЦІ МАЙБУТНІХ УЧИТЕЛІВ МУЗИКИ
}

\author{
Наталя Дермельова \\ старший викладач кафедри музики і хореографії \\ ДВНЗ «Донбаський державний педагогічний університет» \\ м. Слов'янськ, Україна \\ natadermeleva@gmail.com \\ Микола Пшеничних \\ старший викладач кафедри музики і хореографії \\ ДВНЗ «Донбаський державний педагогічний університет» \\ м. Слов'янськ, Україна \\ pshenychnykh@gmail.com
}

\begin{abstract}
Анотація. Статтю присвячено проблемі колективного виконавства в процесі фахової підготовки майбутніх учителів музичного мистецтва. Визначено роль народноінструментального та естрадного оркестрового виконавства в становленні особистості майбутнього вчителя, схарактеризовано особливості методики роботи зі студентами в оркестрі. Автори наголошують на важливості особистісних якостей керівника колективу народноінструментального виконавства для успішного його функціонування, оскільки керівник-викладач має не тільки знати методи керівництва, а й володіти педагогікою як мистецтвом, бути артистом, який прищеплює студентам любов до музичного інструменту, ансамблю, оркестру, музики в цілому, впливає на них передусім власною майстерністю виконання тощо. Висвітлено досвід організації діяльності оркестру народних інструментів ДВНЗ «Донбаський державний педагогічний університет», творчим керівником якого $є$ один з авторів статті.
\end{abstract}

Ключові слова: народно-інструментальне виконавство; професійна підготовка; майбутні вчителі музики; оркестр народних інструментів.

Постановка проблеми в загальному вигляді. В умовах духовного відновлення суспільства, відродження національної культури України, важливе значення надається естетичному розвитку особистості, оволодінню цінностями і знаннями у всіх сферах мистецтва. У реалізації цього відповідального завдання значна роль належить педагогічному керівництву процесом музичного виховання, у тому числі і фахівцям, які працюють в галузі студентського оркестрового виконавства. Колективне народно-інструментальне та естрадне виконавство, як складова музичного мистецтва, $є$ одним із наймогутніших засобів виховання, що надає естетичного забарвлення усьому духовному життю людини.

Народно-інструментальне та естрадне оркестрове виконавство є одним із найдемократичніших видів мистецтва, яке володіє багатим арсеналом засобів ідейно-емоційного впливу на слухачів, різноманітними формами концертної діяльності та участі в масових святах. Успішний розвиток цього жанру 
пов'язаний iз залученням до оркестрів народних та сучасних інструментів молодого поповнення і організації широкої мережі студентських оркестрів. Гра в оркестрі $є$ також формою організації навчально-виховного процесу та дозвілля студентів, виховання їх громадських та естетичних почуттів.

Методика роботи зі студентами має цілий ряд особливостей: психофізіологічних, педагогічних та музично-естетичних. Важливим $\epsilon$ визначення основних навчально-виховних завдань для керівників студентських колективів, надання їм конкретних методичних порад щодо вирішення багатьох проблем. Відомо, що формування повноцінного музичного сприймання вимагає розвитку емоційної сфери студентів, художньо-творчої активності, здатності до розуміння і переживання музики, збагачення естетичного досвіду тощо.

Ефективність цього процесу значною мірою визначається якістю педагогічного керівництва, яке має спрямуватися на створення оптимальних умов для музичного розвитку особистості, забезпечення глибокого осягнення оркестрантами усіх складових навчальної програми: колективної та індивідуальної форм музичного навчання і спілкування; між предметних зв'язків і взаємодіє різних видів мистецтва. Саме тому, в загальній проблемі виховання учасників оркестру особливо важливою $\epsilon$ проблема керування процесом навчання. Її суть полягає у необхідності теоретичного і практичного дослідження процесу заняття й результату його сприймання вихованцями. Однією з головних тенденцій у цій проблемі $\epsilon$ питання передбачуваних i непередбачуваних (стихійних) умов, які можуть сприяти або перешкоджати процесу навчання $\mathrm{i}$ виховання. Оскільки ефективність керівництва навчальним процесом залежить передусім від особистості керівника, особливого значення набуває вдосконалення теоретичної i практичної підготовки майбутніх керівників оркестрів народної та естрадно симфонічної музики.

Аналіз останніх досліджень і публікацій. Дослідженням різних аспектів становлення i розвитку професійних i самодіяльних оркестрів народної та естрадно-симфонічної музики займалися низка вчених (педагогів, музикантів, мистецтвознавців, фольклористів тощо). Праці Є. Бобровникова, Є. Бортника, Л. Гайдамаки, В. Гуцала, О. Незовибатька, І. Скляра, Г. Хоткевича, Л. Черкаського присвячені вивченню історії народного музичного інструментарію, шляхам його удосконалення. У наукових розвідках А. Гуменюка, П. Іванова, В. Комаренка, М. Лисенка, С. Марцинковського розглядаються питання виникнення та формування українського оркестру народних інструментів та естрадно-симфонічного оркестру.

В. Воєводін, . Ільченко, В. Комаренко, С. Юцевич висвітлювали методику роботи з оркестром, особливості його функціонування. В. Дейнега, Д. Пшеничний порушували питання щодо створення репертуару для оркестрів народної та естрадно-симфонічної музики та специфіки виконавської діяльності.

Формулювання цілей статті. Метою статті $\epsilon$ висвітлення проблем та перспектив оркестрового виконавства, а також досвіду організації діяльності 
оркестру народних інструментів у ДВНЗ «Донбаський державний педагогічний університет».

Результати дослідження. Оркестрове виконавство $є$ одним iз найефективніших засобів відтворення творів музичного мистецтва. У наукових та енциклопедичних виданнях поняття «оркестр» трактується як майданчик перед сценою в давньогрецькому театрі. У сучасному розумінні оркестр - це великий колектив музикантів, які грають на різних інструментах і разом виконують твір, написаний для цього інструментального складу. Оркестром також називають сукупність музичних інструментів, на яких грають учасники колективу. Оркестри між собою відрізняються за інструментальним складом (однорідні і мішані), і за призначення у музично-виконавській практиці (духові, естрадні, камерні та ін.) [4, с. 54]. Однією 3 головною категорій народно-оркестрового виконавства $\epsilon$ поняття «оркестр популярної, класичної та сучасної української музики». Оркестр популярної, класичної та сучасної української музики, естрадний оркестр - колектив виконавців на народних та сучасних (наприклад синтезатор) інструментах, які використовуються в автентичному або реконструйованому вигляді та історично побутують у культурі певного етносу. Принцип організації оркестру класичної народної музики пов'язаний з національними особливостями музичної культури певного народу [1, с. 87].

Оркестр популярної, класичної та сучасної української музики є інтернаціональним, єдиним i постійним щодо інструментарію, оскільки формується переважно за національними ознаками. В ньому використовуються головним чином музичні інструменти, які нація вважає невід'ємною частиною своєї духовної культури, своїми національними музичними інструментами. Слід наголосити, що основною особливістю, яка відрізняє оркестр від будь-якого інструментального ансамблю, $є$ групи однорідних інструментів, або їх ще називають сім'ями оркестрових інструментів. Сім'я музичних інструментів - це об'єднання всіх різновидів певного музичного інструменту (враховуючи основного представника). Вони об'єднані за основним конструктивним принципом i, як правило, ці інструменти однохарактерні за звучанням, але різні за розміром i регістровим розміщенням діапазону. Інструменти, 3 яких утворюються головні оркестрові групи називаються основними, а ті, які не входять до цих груп, мають назву епізодичних [2, с. 76]. На сьогодні в Україні побутують два типи оркестрів популярної, сучасної та класичної української музики - струнно-смичковий та струнно-щипковий. Струнно-смичковий оркестр називають українським, а струнно-щипковий - академічним. Як бачимо, дослідники визначають назву оркестру саме за провідною групою колективу.

Поряд $з$ професійними оркестрами в народно-оркестровому та естрадному виконавстві існують і навчальні оркестри. Це колективи, які функціонують при музичних академіях, університетах та інститутах культури, мистецьких відділеннях педагогічних університетів, музичних училищах та коледжах тощо. Навчальні оркестри $є$ творчими лабораторіями, у яких здійснюється 
експериментальна робота щодо формування складу, оновлення репертуару. Завдяки систематичній чітко спланованій навчально-виховній роботі підвищується виконавська майстерність виконавців. Творчій діяльності навчальних колективів притаманна орієнтація на професіоналізм зі збереженням найкращих традицій оркестрового жанру. Яскравим прикладом навчального колективу є студентський оркестр народних інструментів ДВНЗ ДДПУ, кафедри музики і хореографії (художній керівник - М. Пшеничний).

Діяльність колективу характеризується опорою на репертуар західноєвропейської, російської та української класики, та сучасних композиторів. Усталеність інструментального складу, злагодженість звучання оркестрових груп, наближають його за своїми характерними ознаками до професійного. Оркестр народних інструментів створено в 1986 р. За час існування колективу його керівником був баяніст, диригент, випускник Донецького музично-педагогічного інституту М. Аверченко. На сьогодні керівником колективу $\epsilon$ старший викладач кафедри музики i хореографії, випускник Петрозаводської консерваторії, педагог-музикант М. Пшеничних. У співпраці 3 художнім керівником концертмейстери провідних груп оркестру чотириструнних домр та балалайок.

У репертуарі оркестру різножанрові класичні та сучасні твори, серед яких вступ до опери «Алеко» С. Рахманінова, арія Марфи з опери «Царская невеста» М. Римського-Корсакова, «Контрданс» Л. Бетховена, «El vito» Лопе, низка власних перекладень, аранжувань та оркеструвань українських народних пісень, романсів. Студентський оркестр народних інструментів відрізняється широкою динамічною палітрою завдяки групі багатотембрових готово-виборних баянів та акордеонів, що дає можливість виконувати твори української і зарубіжної класики, сучасні оригінальні твори, обробки народної танцювальної музики, супроводу вокальних творів в аранжуванні та оркеструванні керівника колективу. Закладені традиції народно-оркестрового виконавства, зберігаються в колективі і примножуються. Керівник оркестру професійно підходить до виконавського аспекту роботи у студентському оркестрі. Оркестрові групи звучать збалансовано i злагоджено завдяки організації та проведення індивідуальних занять 3 опанування навичок гри на оркестрових інструментах. Сформованість ансамблевих навичок, дотримання єдиних аплікатурних рішень, штрихів i тембрового забарвлення у виконавців однієї партії, це той результат систематичного і послідовного розвитку індивідуальних музично-виконавських умінь кожного учасника колективу.

Методика роботи 3 оркестром включає в себе: формування стійкої зацікавленості студентів до колективного оркестрового виконавства; поетапну реалізацію бажання студентів до пошуку себе і самоствердження у всіх видах колективної діяльності 3 урахуванням психофізіологічних характеристик студентів та їх індивідуальних здібностей; інтенсифікацію навчально-виховної роботи на грунті використання прогресивних методик, дозволяючи збільшити 
об’єм та якість оркестрового виконання; організацію багатовекторного i багатопредметного оркестрового життя та соціокультурної діяльності 3 пошуково-творчими елементами, включаючи різноманітні види і жанри разом із формами внутрішнього та зовнішнього напрямів роботи; створення позитивного мікросередовища 3 метою створення психологічного комфорту в музичній діяльності студентів.

Висновки 3 дослідження і перспективи подальших розвідок у цьому напрямі. Таким чином, педагогічне керівництво навчальним процесом має специфічний характер, оскільки керівник-викладач має не тільки знати методи керівництва, а й володіти педагогікою як мистецтвом, бути артистом, який прищеплює у студентів любов до музичного інструменту, ансамблю, оркестру, музики в цілому, впливає на них передусім власною майстерністю виконання тощо. Отже, орієнтація навчальних колективів на репертуар українських композиторів, певна стабільність інструментального складу, злагодженість оркестрового звучання, компетентне керівництво оркестром є запорукою високої виконавської майстерності оркестру і наближенням його за своїми характерними ознаками до професійного.

\title{
СПИСОК ВИКОРИСТАНИХ ДЖЕРЕЛ
}

1. Давидов, М. (2005). Історія виконавства на народних інструментах. (Українська академічна школа. Київ: КНМАУ ім. П. І. Чайковського.

2. Дейнега, В. (2002). Музичний інструментарій як показник специфіки оркестру народних інструментів. Науковий вісник НМАУ ім. П. І. Чайковського, 22, 119 - 129.

3. Ільченко, О. (2004). Народне оркестрове виконавство: аматорство та проблеми художності. Київ: КДІК.

4. Келдыш, Г. (1990). Музыкальный энциклопедический словарь. Москва: Советская энциклопедия.

5. Черкаський, Л. (2003). Українські народні музичні інструменти. Київ: Техніка.

\section{ОПЫТ ОРГАНИЗАЦИИ КОЛЛЕКТИВНОГО НАРОДНО- ИНСТРУМЕНТАЛЬНОГО ИСПОЛНИТЕЛЬСТВА В ПОДГОТОВКЕ БУДУЩИХ УЧИТЕЛЕЙ МУЗЫКИ}

\author{
Наталья Дермелева \\ старший преподаватель кафедры музыки и хореографии
}

ГВУЗ «Донбасский государственный педагогический университет»

г. Славянск, Украина

natadermeleva@gmail.com

Николай Пшеничных

старший преподаватель кафедры музыки и хореографии

ГВУЗ «Донбасский государственный педагогический университет»

г. Славянск, Украина

pshenychnykh@gmail.com 


\begin{abstract}
Аннотация. Статья посвящена проблеме коллективного исполнительства в процессе профессиональной подготовки будущих учителей музыкального искусства. Определена роль народно-инструментального и эстрадного оркестрового исполнительства в становлении личности будущего учителя, охарактеризованы особенности методики работы со студентами в оркестре. Авторы подчеркивают важность личностных качеств руководителя коллектива народно-инструментального исполнительства для успешного его функционирования, поскольку руководитель-преподаватель имеет не только знать методы руководства, но и владеть педагогикой как искусством, быть артистом, прививает студентам любовь к музыкальному инструменту, ансамбля, оркестра, музыки в целом, влияет на них прежде всего собственным мастерством исполнения и тому подобное. Освещен опыт организации деятельности оркестра народных инструментов ДВНЗ «Донбасский государственный педагогический университет», творческим руководителем которого является один из авторов статьи.
\end{abstract}

Ключевые слова: народно-инструментальное исполнительство; профессиональная подготовка; будущие учителя музыки; оркестр народных инструментов.

\title{
EXPERIENCE OF THE COLLECTIVE FOLK INSTRUMENTAL PERFORMANCE ORGANIZATION IN THE FUTURE MUSIC TEACHERS' TRAINING
}

\author{
Natalia Dermelova \\ Senior Lecturer of the Department of Music and Choreography \\ SHEE "Donbas State Pedagogical University" \\ Sloviansk, Ukraine \\ natadermeleva@gmail.com \\ Mykola Pshenychnykh \\ Senior Lecturer the Department of Music and Choreography \\ SHEE "Donbas State Pedagogical University" \\ Sloviansk, Ukraine \\ pshenychnykh@gmail.com
}

\begin{abstract}
The article is devoted to the problem of collective performance in the process of professional training of future teachers of musical art. The folk instrumental performances are one of the most democratic forms of art, which has a rich arsenal of means of ideological and emotional influence on listeners, various forms of concert activity and participation in mass festivals. The successful development of this genre is associated with the involvement of a broad network of student collectives in folk instruments orchestras. The participation in the orchestra is also a form of organization of the educational process and leisure of the students, education of their social and aesthetic feelings. The scholars E. Bortnik, L. Haydamaka, V. Hutsalo, I. Skliar, H. Khotkevych were engaged in the study of various aspects of the formation and development of professional and amateur orchestras of folk and pop symphonic music.

The role of folk instrumental and variety orchestral performance in the developing of the personality of the future teacher is determined, features of the methodology of work with students in the orchestra are characterized. The authors emphasize the importance of personal qualities of the leader of the collective of folk-instrumental performances for its successful functioning, since the teacher-instructor must not only know the management methods, but also have a pedagogy as an art, be an artist who instills students love for a musical instrument, ensemble, orchestra, music in general,
\end{abstract}


affects them primarily by their own mastery of performance, etc. The experience of organizing the activity of the Orchestra of Folk Instruments of the State Higher Educational Establishment "Donbas State Pedagogical University" is elucidated, since one of the authors of the article is the creative director.

Key words: folk instrumental performance; professional training; future music teachers; Orchestra of folk instruments.

\section{REFERENCES (TRANSLATED AND TRANSLITERATED)}

1. Davydov, M. (2005). History of the performance on folk instruments. (Ukrainian Academic School. Kyiv, Ukraine: KIAMU named after P. I. Tchaikovskyi.

2. Deineha, V. (2002). Musical instruments as an indicator of the specifics of the folk instrument orchestra. Naukovyi visnyk NMAU im. P. I. Chaikovskoho, 22, 119 - 129.

3. Ilchenko, O. (2004). Folk orchestra performance: amateur and artistic problems. Kyiv, Ukraine: KSCA.

4. Keldysh, G. (1990). Music Encyclopedic Dictionary. Moscow: Soviet Encyclopedia.

5. Cherkaskyi, L. (2003). Ukrainian folk musical instruments. Kyiv, Ukraine: Tekhnika.

Матеріали надійшли до редакції 27.11.2018 p. 